\title{
Effect of Pollenizer Distance and Selective Fruitlet Abscission on Outcrossing Rate and Yield in 'Tommy Atkins' Mango
}

\author{
A. Dag, D. Eisenstein, and S. Gazit \\ The Kennedy-Leigh Centre for Horticultural Research, Faculty of Agriculture, The Hebrew University of \\ Jerusalem, P.O. Box 12, Rehovot 76100, Israel \\ R. El-Batsri and C. Degani \\ Institute of Horticulture, Agricultural Research Organization, The Volcani Center, Bet Dagan, Israel
}

\begin{abstract}
AdDitional INDEX words. Mangifera indica, isozyme analysis, inbreeding depression, triosephosphate isomerase
Abstract. Postzygotic self-incompatibility has been reported in several Indian mango (Mangifera indica $\mathrm{L}$.) commercial cultivars. Floridian cultivars, on the other hand, have been planted in solid blocks and seem to be self-fertile. Isozyme analysis enabled us to determine outcrossings rates at the fruitlet and fruit stages in the Floridian 'Tommy Atkins' ('Tommy'). Two commercial mango orchards consisting of adjacent solid blocks of 'Maya' and 'Tommy' were studied. This combination offered a unique opportunity to identify each individual fruitlet or fruit as selfed or outcrossed by TPI isozyme analysis. A consistent and significant increase in outcrossing rate during fruit development was found: the average outcrossing rate increased from $10 \%$ and $13 \%$ in fruitlets to $66 \%$ and $73 \%$ in mature fruit in the two 'Tommy' blocks surveyed. This 6-fold increase is the result of selective abscission of selfed progeny. A significant inverse correlation was found between the distance of 'Tommy' trees from the 'Maya' block and the outcrossing rate in mature fruit. No significant correlation between distance from 'Maya', or outcrossing rate, and yield was observed, suggesting that the practice of planting 'Tommy' in solid blocks is sound.
\end{abstract}

Postzygotic self-incompatibility was reported in several commercial Indian cultivars ('Bombay Green', 'Chausa', 'Langra', and 'Dasheri') in the early 1970s (Sharma and Singh, 1970; Singh and Sharma, 1972), and more recently confirmed (Rao et al., 1984). In those hand-pollination studies, initial fruit set did occur after self-pollination. However, the endosperm of selfed fruitlets showed clear signs of degeneration and $\approx 1$ month after set they abscised. A similar phenomenon was found in the polyembryonic 'Turpentine' in Israel (Roizman, 1984).

Floridian mango cultivars ['Haden', 'Tommy Atkins' ('Tommy'), 'Kent', 'Keitt', and 'Van Dyke'] (Campbell, 1992) predominate in commercial orchards outside southeast Asia. Little evidence is available regarding the need for cross-pollination in these cultivars .'Zill' pollen germinated faster on stigmas of detached 'Haden' flowers, relative to self pollen (de Wet et al., 1989). Conflicting information exists on the effect of adjacent pollenizers on 'Haden' yield in Florida. One report (Ruehle and Lynch, 1939) concluded that there is a clear beneficial effect, whereas another did not (Ledin, 1958). Young (1942) did not find any significant difference between the final set of selfed or crossed hand-pollinated 'Haden' flowers. In Israel it was found that 'Haden', 'Maya', 'Zillate', and 'Irwin' trees caged with a beehive produced good yields with or without the presence of pollenizer trees (Degani et al., 1992; Roizman, 1984; Yutko, 1995).

The fact that the Floridian cultivars investigated to date have been found to be self-fertile does not exclude the possibility that other Floridian cultivars may be self-sterile, or that cross-pollination may increase fruit set and yield in self-fertile mango cultivars, as suggested by Popenoe (1917). 'Tommy' is of specific interest, because it is one of the most widely grown commercial cultivars in

Received for publication 12 May 1997. Accepted for publication 26 Jan. 1998. Contribution from the Agricultural Research Organization, The Volcani Center, Bet Dagan, Israel, no. E-2097, 1997 series. The cost of publishing this paper was defrayed in part by the payment of page charges. Under postal regulations, this paper therefore must be hereby marked advertisement solely to indicate this fact.
Florida (Campbell, 1992) and Israel, yet its productivity tends to be lower than that of the other leading commercial cultivar 'Keitt'. 'Tommy' is often planted in solid blocks and is considered selffertile. However, there is no information on the effect of cross- vs. self-pollination on its yield.

The development of isozymes as genetic markers in mango (Degani et al., 1990) has enabled unequivocal determinations of the pollen parent of fruit in several specific combinations of two cultivars. In the first such study (Degani et al., 1997a), the outcrossing rate in mature fruit was determined in adjacent blocks of 'Maya' and 'Tommy', at different distances from the pollenizer blocks; however, yield was not recorded.

Hermaphroditic plants often produce far more flowers than mature fruit (Bawa and Webb, 1984; Lloyd, 1980; Stephenson,

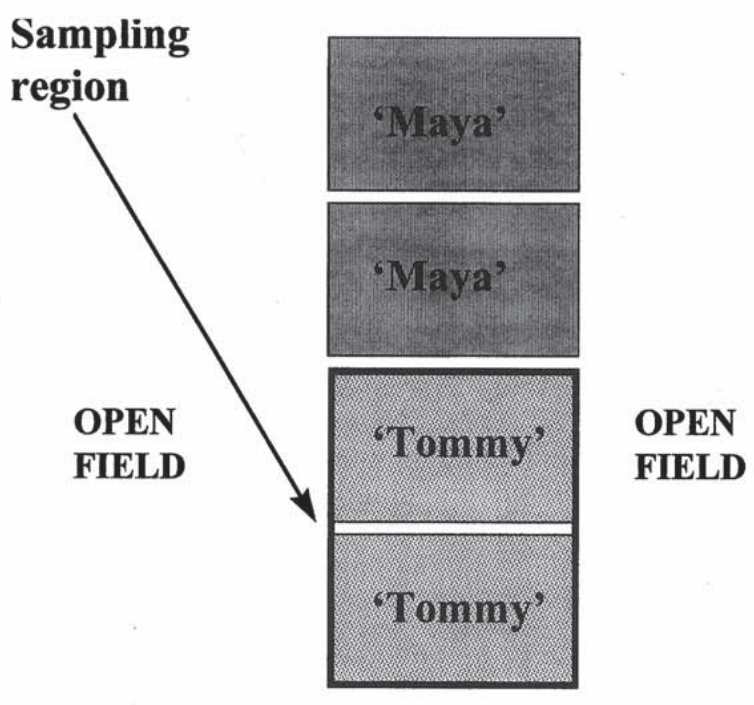

Fig. 1. Schematic map of the mango blocks in the Merom Golan orchard (width and length of each block 120 and $132 \mathrm{~m}$, respectively). 


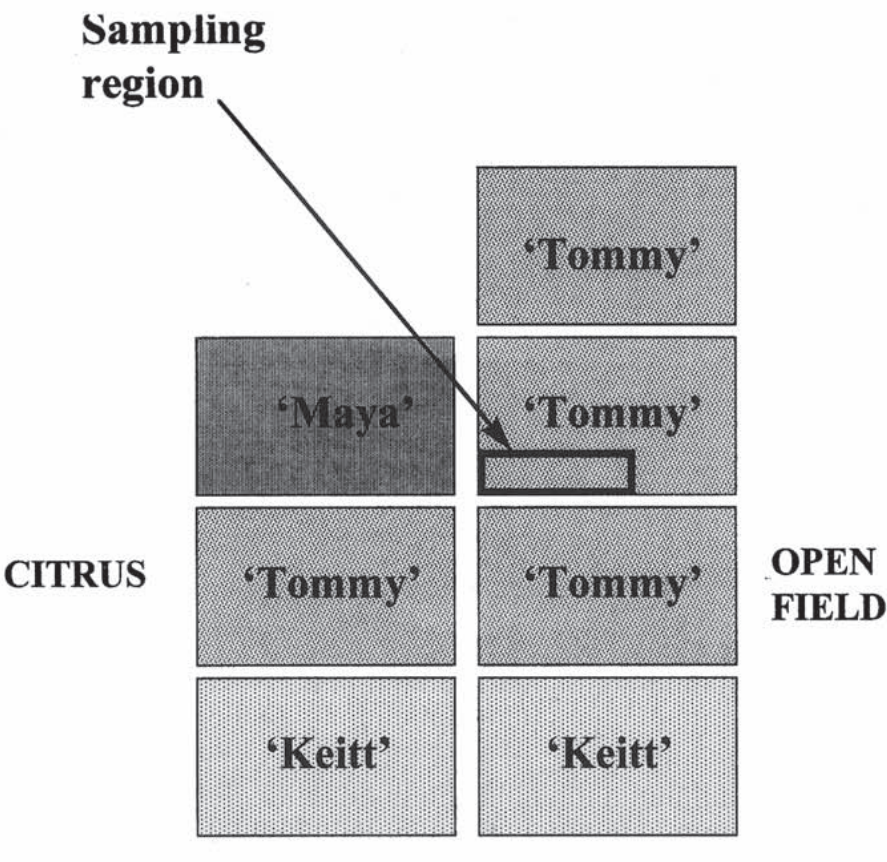

Fig. 2. Schematic map of the mango blocks in the Neve Ur orchard (width and length of each block 90 and $125 \mathrm{~m}$, respectively).

1981). Apparently excess flowers allow the plant to control the genetic quality of its offspring by aborting inferior progeny (Janzen, 1977; Lloyd, 1980, Stephenson, 1981). Selective abscission of selfed progeny was found in Litchi chinesis Sonn. (Degani et al., 1995), Persea americana Mill (Degani et al., 1986; 1989), Banksia spinulosa Smith (Vaughton and Carthew, 1993), and other crops (Stephenson, 1981; Stephenson and Winsor, 1986).

The aim of this study was to 1) determine the effect of self vs. cross-pollination on mango fruitlet survival and 2) determine the effect of pollenizer proximity on outcrossing rate and yield.

\section{Materials and Methods}

CAGED TREes. Two 'Tommy' trees were caged at the end of February 1994 before ings of $1.5 \times 1.5 \mathrm{~mm}$ ) before flowering at the Faculty of Agriculture experimental mango orchard in Rehovot. A beehive was placed inside each cage on 20 Mar. Twenty fruitlets, weighing 2 to $6 \mathrm{~g}$, were sampled from each tree to confirm that the isozyme pattern of selfed 'Tommy' fruitlet endosperm is the same as that of mature leaves.

OrChard STUdies. We located two commercial mango orchards (Merom Golan and Neve Ur) consisting of adjacent solid blocks of 'Maya' and 'Tommy'. This arrangement allowed the identification of each flowering, with a 15-mesh screen (open-

individual fruitlet or fruit as selfed or outcrossed by TPI (triosephosphate isomerase) isozyme analysis. For the locus Tpi, 'Maya' and 'Tommy' are homozygous $a a$ and $b b$, respectively (Degani et al., 1990). Thus, hybrid fruit of 'Tommy' $x$ 'Maya' is identified by its heterozygous ( $a b)$ Tpi genotype, and 'Tommy' selfed-fruit is identified by its $b b$ genotype.

Young 'Tommy' fruitlets (2 to $6 \mathrm{~g}$ ) and mature fruit were randomly sampled in 1994 in Neve Ur and in 1995 in Merom Golan. In 1994, only mature ‘Tommy' fruit were randomly sampled in Merom Golan.

The Merom Golan orchard is located to the north of the Sea of Galilee, and was studied for 2 consecutive years. The 'Tommy' block had been planted in 1983 and consisted of 20 rows $(6 \mathrm{~m}$ apart), each with 42 trees ( $5 \mathrm{~m}$ apart). At its northern side it bordered with a 'Maya' block (Fig. 1). In both years, mature fruit were sampled in July from distances of 10, 15, 25, 45, 85, and 165 m away from the 'Maya' block. In 1994, 60 fruit were sampled at each distance: four replications (individual trees) $\times 15$ fruit per replication. In 1995, 120 fruitlets and fruit were sampled at each distance: Four replications (groups of three trees each) $\times 30$

Fig. 3. Hybrid rate and yield in 'Tommy' fruit at six distances from a 'Maya' block; study conducted at Merom Golan, in 1994. The bars are SE.
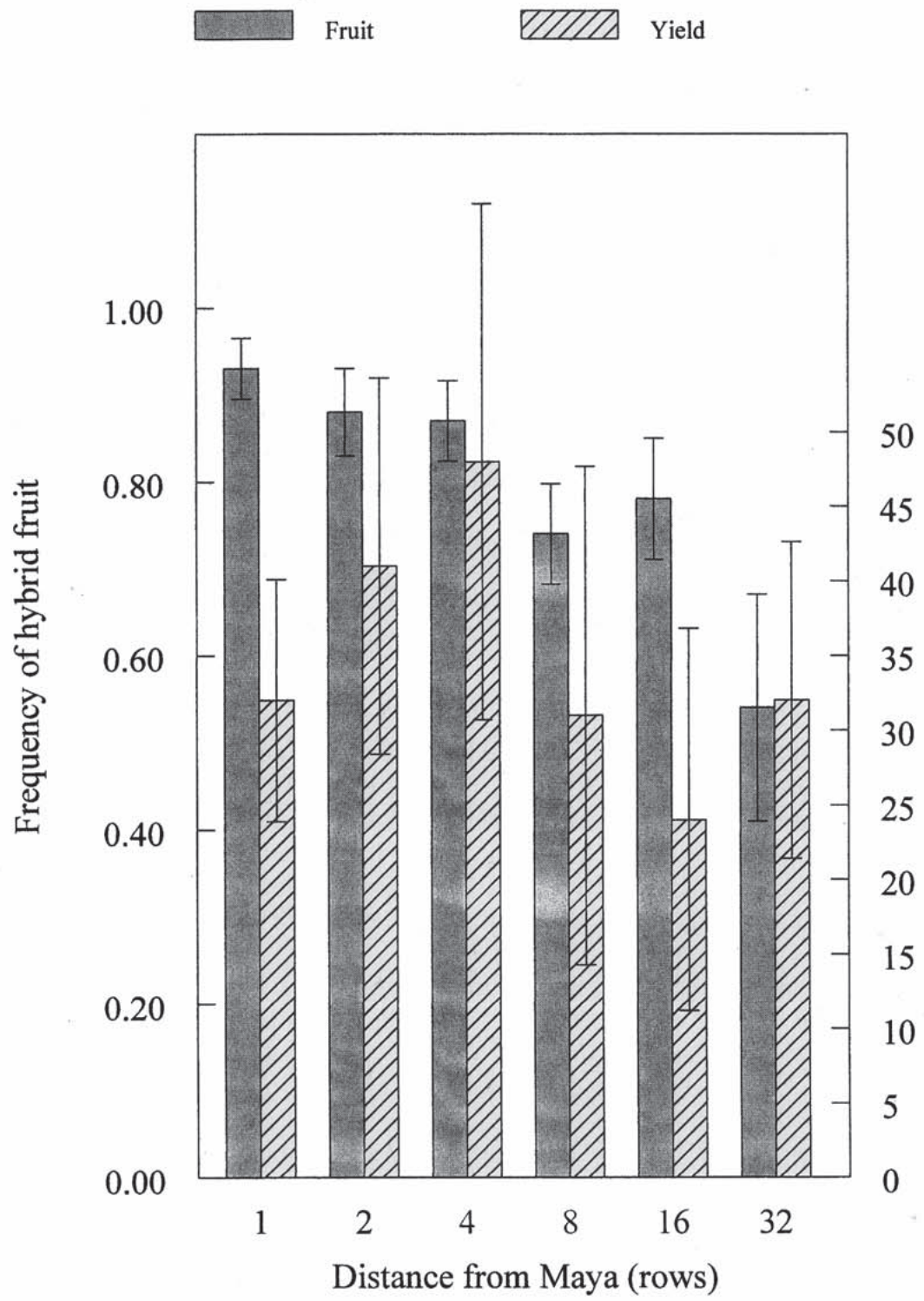

J. AMER. SOC. HorT. SCI. 123(4):618-622. 1998. 
$\square$

Fruitlet

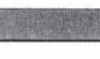

Fruit

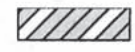

Yield

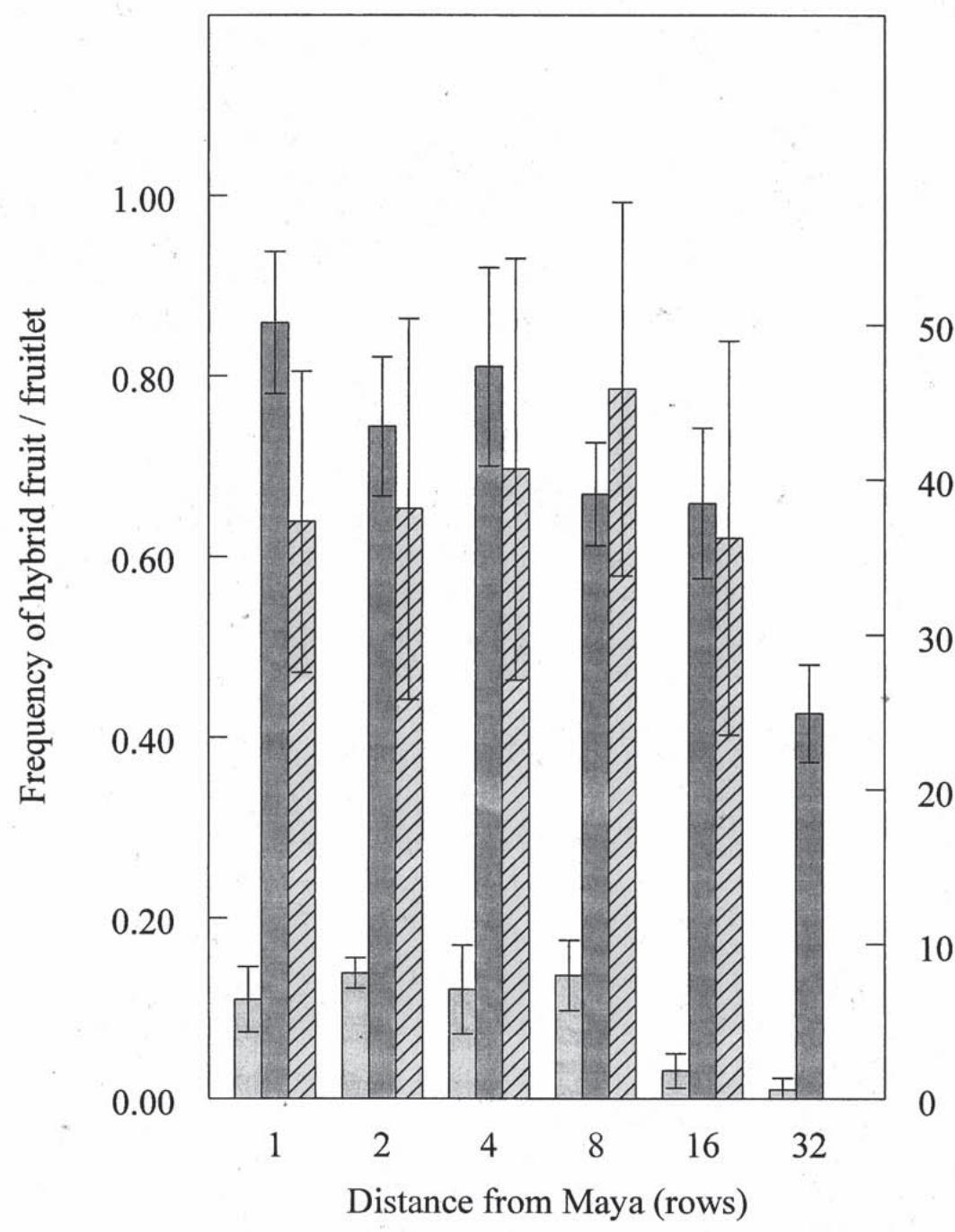

mature leaves from the seedlings were used for the TPI analysis (Degani et al., 1990). Germination rates were $80 \%, 70 \%$, and 38\% for Neve Ur 1994, Merom Golan 1994 and 1995 , respectively. The low rate in 1995 apparently occurred because germination media from 1994 was reused without sterilization. The factor responsible for low germination rate in 1995 did not discriminate against selfed seeds; outcrossing percentage was slightly lower in $1995 \mathrm{com}$ pared to 1994 (Figs. 3 and 4). The number of seedlings analyzed was 319,253 and 273, for Neve Ur 1994, Merom Golan 1994 and 1995 , respectively.

\section{Results}

Tpi-GENOTYPE IN THE ENDOSPERM OF FRUITLETS FROM CAGED 'TOMMY' TREES. All 40 fruitlets sampled were found to have endosperm with the same Tpi genotype $(b b)$ as in leaves from the parent 'Tommy' trees (Degani et al., 1990). This result confirmed that fruitlet endosperm could be used for unequivocal paternity analysis.

OUTCROSSING RATE IN FRUITLETS AND FRUIT AT INCREASING DISTANCES FROM THE POLLENIZER BLOCK. Outcrossing (hybrid) rates in 'Tommy' fruitlets and fruit at increasing distances from the 'Maya' block (Figs. 1 and 2) are presented for Merom Golan in Figs. 3 (mature fruit only) and 4, and for Neve Ur in Fig. 5. The percent of outcrossed progeny for mature fruit was $\approx 6$-fold higher than percent outcrossed for young fruitlets (Figs. 4 and 5). The percent of outcrossed fruitlets were 10 and 13 , and for mature fruit, 66 and 73, for Merom Golan and Neve Ur orchards, respectively. In the two orchards, the increase was consistent and significant $(P$ $<0.01)$ at all distances from the 'Maya' block.

There was a significant decrease in the proportion of mature outcrossed fruit with increasing distance from the 'Maya' pollenizer block (Figs. 3-5). This inverse correlation was represented by linear regression curves: OC $=0.87-0.02 \mathrm{r}$ for Neve Ur $1994\left(R^{2}\right.$ $=0.91) ; \mathrm{OC}=0.91-0.01 \mathrm{r}\left(R^{2}=0.90\right)$ and $\mathrm{OC}=0.79-0.01 \mathrm{r}\left(R^{2}\right.$ $=0.94)$ for Merom Golan in 1994 and 1995, respectively $(\mathrm{OC}=$ Outcrossed fruit, $r$ = row from 'Maya' block). In both orchards, the percent of outcrossed fruitlets was also much lower at great distance from the pollenizer block than at close proximity (Figs. 4 and 5), but, no consistent trends were found. Both sites were characterized by mid-distance outcrossing rates higher than expected, at $45 \mathrm{~m}$ in Neve Ur and at 25 to $45 \mathrm{~m}$ in Merom Golan. We rechecked all trees in the studied 'Tommy' blocks. In Neve Ur we found, $45 \mathrm{~m}$ from the 'Maya' block, one 'Tommy' tree with a big 'Maya' branch, and in Merom Golan we found a 'Palmer' tree (Tpi genotype $a b) 50 \mathrm{~m}$ from the 'Maya' block.

THE RELATIONSHIP BETWEEN FREQUENCY OF OUTCROSSED FRUTT, DISTANCE, AND YIELD. The number of mature fruit carried by the sampled trees was determined at harvest (Figs. 3-5). Neither distance nor frequency of outcrossed mature fruit was correlated with yield. 


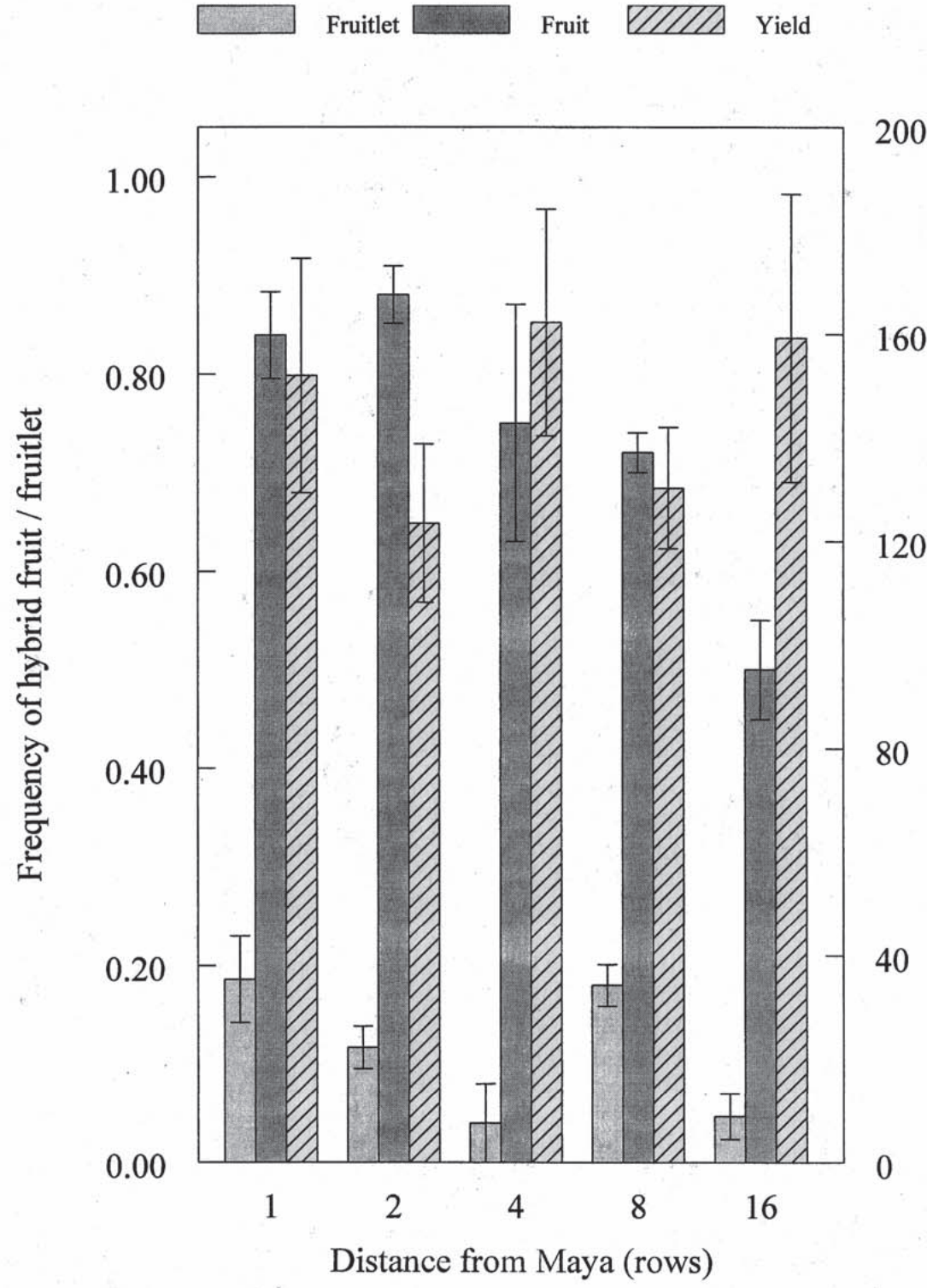

should predominate. Nevertheless, Degani et al. (1997a) found a very high outcrossing rate in mature fruit of 'Tommy' and 'Maya' mangos, even $108 \mathrm{~m}$ away from the pollenizer block. Dag et al. (1997) found the same phenomenon in 'Lily' at $60 \mathrm{mfrom}$ 'Tommy'. Our results corroborate these findings for 'Tommy' (Figs. 3-5); even at $165 \mathrm{~m}$ away from the 'Maya' block, about half of the mature fruit originated from outcrossing. Mango breeders using open pollination progeny should be aware of these findings.

The 6-fold increase in the frequency of outcrossed progeny from the 2 to $6 \mathrm{~g}$ fruitlet stage $(\approx 1$ month old $)$ to mature fruit indicates that the high rate of outcrossed mature fruit in mango (Figs. 3-5) (Degani et al., 1997a) does not reflect the actual rate of crosspollination; it is mainly a result of selective fruitlet abscission. The actual increase in outcrossing rate from fruit set to fruit maturity is apparently much higher. A mature mangotreeproduces several millions of flowers. Only $\leq 0.1 \%$ of its perfect flowers develop into mature fruit (Singh, 1960). Massive fruitlet abscission was specifically reported for 'Tommy' (Nunez-Elisea and Davenport, 1983), with most of the fruitlet drop occurring during the first month. Thus, it seems reasonable that the increase in outcrossing rate was much higher than 6-fold. As a result, a minuscule rate of cross-pollination could be transformed by selective abscission to a substantial percentage of hybrids at harvest. The same phenomenon was found in other fruit crops (Degani etal., 1986, $1989,1995,1997 b)$, suggesting that selective abscission is a widespread phenomenon for plants that have profuse bloom and low rate of final fruit set.

In unisexual or self-incompatible cultivars, effective cross-pollination can be determined readily and accurately by monitoring fruit set. In several such plants, pollinated by insects, fruit set rate was found to decrease sharply with increasing distance from the foreign pollen source. In male sterile cotton, the decrease found was 10-fold or more for the first $20 \mathrm{~m}$ (Mungomery and Glassop, 1969). In selfincompatible plum, fruit set decreased from $7 \%$ in trees adjacent to the pollenizer to $\leq 1 \%$, four rows or more away (Free, 1962). In contrast, when the plant is self-fertile, there is no easy way to differentiate between cross- and self-pollination initial set. With 'Tommy' we had to wait until the amount of embryo and endosperm was large enough to enable separation and isozyme analysis.

Table 1. Pericarp and seed average mass of selfed vs. outcrossed 'Tommy' progeny, Merom Golan, 1994.

\begin{tabular}{lccc}
\hline \hline & $\begin{array}{c}\text { Fruit } \\
\text { examined } \\
(\text { no. })\end{array}$ & $\begin{array}{c}\text { Pericarp } \\
\text { mass } \\
(\mathrm{g})\end{array}$ & $\begin{array}{c}\text { Seed } \\
\text { mass } \\
(\mathrm{g})\end{array}$ \\
\hline Progeny & 202 & 279 & 19.5 \\
Outcrossed & 51 & 273 & 17.0 \\
Selfed & & NS & $*$ \\
\hline
\end{tabular}

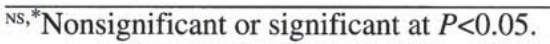


The fact that crossed 'Tommy' fruit had significantly heavier seeds than selfed ones (Table 1) indicates greater vigor of the former and probably reflects greater ability to compete for nutrients. However, competition and inbreeding depression may be involved with the massive fruitlet abscission in self fertile mango. As a result of inbreeding degeneration (Singh and Sharma, 1972), self.'Tommy' fruitlets may abscise even when there is no competition (Charlesworth and Charlesworth, 1987; Sedgley and Griffin, 1989). The fact that no correlation was found between the distance from the pollenizer block or the outcrossing rate and yield (Figs. 35) indicates that both selfed or crossed fruit may survive to realize the tree capacity. Apparently, a sufficient number of selfed 'Tommy' fruitlets had the ability to develop into mature fruit. Similar phenomenon was reported for 'Mauritius', a self-fertile lychee cultivar (Degani et al., 1995; Stern et al., 1993 ).

Our results (Figs. 3-5) show that 'Tommy' productivity was not influenced by its vicinity to a large 'Maya' block. Hence, there is no reason to change the practice of planting 'Tommy' in solid blocks. The absence of an adjacent pollenizer may even be an advantage, as selfed 'Tommy' fruit have a more desirable fruit to seed ratio (Table 1).

\section{Literature Cited}

Anderson, D.L., M. Sedgley, J.T. Short, and A.J. Allwood. 1982. Insect pollination of mango in northern Australia. Austral. J. Agr. Res. 33:541548.

Bawa, K.S. and C.J. Webb. 1984. Flower, fruit and seed abortion in tropical forest trees: Implications for the evolution of parental and maternal reproductive patterns. Amer. J. Bot. 71:736-751.

Campbell, R.J. 1992. Guide to mangos in Florida. Fairchild Tropical Garden, Miami, Fla.

Charlesworth, D. and B. Charlesworth. 1987. Inbreeding depression and its evolutionary sequences. Annu. Rev. Ecol. Syst. 18:237-268.

Dag, A. and S. Gazit. 1996. Mango pollinators in Israel. Alon Hanotea 40:458-465 (in Hebrew).

Dag, A., D. Eisenstein., C. Degani., R. El-Batsri, M. Zelig, and S. Gazit. 1997. Tommy Atkins mango as pollenizer for Lily. Acta Hort. 455:209216.

Davenport, T.L. and R. Nunez-Elisea. 1997. Reproductive physiology, p. 69-146. In: R.E. Litz (ed.). The mango: Botany, production and uses. CAB Intl., Wallingford, U.K.

Degani, C., A. Goldring, S. Gazit, and U. Lavi. 1986. Genetic selection during the abscission of avocado fruitlets. HortScience 21:1187-1188.

Degani, C., A. Goldring, and S. Gazit. 1989. Pollen parent effect on outcrossing rate in 'Hass' and 'Fuerte' avocado plots during fruit development. J. Amer. Soc. Hort. Sci. 114:106-111.

Degani, C., R. El-Batsri, and S. Gazit. 1990. Enzyme polymorphism in mango. J. Amer. Soc. Hort. Sci. 115:844-874.

Degani, C., M. Cohen., R. El-Batsri, and S. Gazil. 1992. PGI isozyme diversity and its genetic control in mango. HortScience 27:252-254.

Degani, C., R.A. Stern., R. El-Batsri, and S. Gazit. 1995. Pollen parent effect on the selective abscission of 'Mauritius' and 'Floridian' lychee fruitlets. J. Amer. Soc. Hort. Sci. 120:523-526.

Degani, C., O. Yutko, R. El-Batsri, and S. Gazit. 1997 a. Outcrossing rate in adjacent 'Maya' and 'Tommy Atkins' mango blocks. Scientia Hort. 70:25-30.

Degani, C., R. El-Batsri, and S. Gazit. 1997b. Outcrossing rate, yield and selective fruit abscission in 'Ettinger'-'Ardit' avocado plots. J. Amer. Soc. Hort. Sci. 122:813-817.

de Wet, E., P.J. Robbertse, and H.T. Groeneveld. 1989. The influence of temperature and boron on pollen germination in Mangifera indica L. S. Afr. J. Plant Soil 6:230-234.

Frce, J.B. 1962. The effect of distance from pollenizer varieties on the fruit set on trees in plum and apple orchards. J. Hort. Sci. 37:262-271.

Janzen, D.H. 1977. A note on optimal mate selection in plants. Amer. Natur. 111:365-371.

Ledin, B.R. 1958. Can Haden yields be increased by interplanting with Saigon mango. Proc. Fla. Mango Forum 1958:12-14.

Lloyd, D.G. 1980. Sexual strategies in plants I. An hypothesis of serial adjustment of maternal investment during one reproductive session. New. Phytol. 86:69-79.

Mungomery, V.E. and A.J. Glassop. 1969. Natural cross-pollination of cotton in central Queensland. J. Animal Sci. 26:69-74.

Nunez-Elisea, R. and T.L. Davenport. 1983. Abscission and ethylene production in mango (Mangifera indica $L$.) fruit cv. Tommy Atkins. Proc. Fla. State Hort. Soc. 96:185-188.

Popenoe, W. 1917. The pollination of the mango. USDA Bul. 542.

Rao, M.R., S.N. Rao, and O. Rama-Rao, 1984. Studies on flowering, sex ratio and self-incompatibility of important south Indian cultivars and hybrid of mango. India J. Hort. 41:58-61.

Roizman, Y. 1984. The involvement of different factors in the process of pollination, fruit set and embryo development of monoembryonic and polyembryonic mango varieties. MS thesis, Hebrew Univ. of Jerusalem, Rehovot, Israel (in Hebrew).

Ruehle, G.D. and S.J. Lynch. 1939. Mango yields increased by cross pollination. Florida Grower (July):57-58.

Sedgley, M. and A.R. Griffin. 1989. Sexual reproduction of tree crops. Academic Press, London. p. 204-213.

Sharma, D.K. and R.N. Singh. 1970. Self incompatibility in mango. Hort. Res. 10:108-118.

Singh, L.B. 1960. The mango. Leonard Hill, London.

Singh, R.N. 1988. Insect pollinators of mango and their role in fruit set. Acta. Hort. 231:629-631.

Singh, R.N. and D.K. Sharma 1972. Some pollination problems in mango. Acta Hort. 24:134-138.

Stephenson, A.G. 1981. Flower and fruit abortion: proximate causes and ultimate functions. Annu. Rev. Ecol. Syst. 12:253-279.

Stephenson, A.G. and J.A. Winsor. 1986. Lotus corniculatus regulates offspring quality through selective fruit abortion. Evolution 40:453458.

Stern, R.A., S. Gazit., R. El-Batsri, and C. Degani. 1993. Pollen parent effect on outcrossing rate, yield and fruit characteristics of 'Floridian' and 'Mauritius' lychee. J. Amer. Soc. Hort. Sci. 118:109-114.

Vaughton, G. and S.M. Carthew. 1993. Evidence for selective fruit abortion in Banksia apinulosa (Proteacea). Biol. J. Linnean Soc. $50: 35-46$,

Young, T.W. 1942. Investigation of the 'Haden' mango in Florida. Proc. Fla. State. Hort. Soc. 55:106-110.

Yutko, O. 1995. Self and cross pollination in open and caged mango trees and its effect on fruit set and yield. MS thesis, Hebrew Univ. of Jerusalem, Rehovot, Israel (in Hebrew). 